\title{
'Peace is not just the suspension of war:' peace communication on Twitter
}

Aistè Klimašauskaitè

Department of Public Policy, Tel Aviv University, Tel Aviv, Israel

\begin{abstract}
'Strategic communication is something we are very bad at', tells us a tweet from the Geneva Peace Week. One of the examples of strategic communication is public engagement content on Twitter. Empirical studies, however, never looked at public engagement content about peace on Twitter. In turn, I use grounded theory approaches to explore and map peace communication among seven research organizations and events in the West. My data set comprises a total of 9,874 tweets in English. Thematic coding with Atlas.ti results in 4,274 codes that are grouped into 63 distinct themes. I find sustainable peace as the main type of peace in data. Yet, the themes that presumably contribute to it - health, accountability, trust, and transparency, among others - are marginal. While gender is among the dominant themes, it emerges disconnected, with a lack of meaningful integration of it in other topics such as health or participation. A pattern emerges of the level of view that is mainly positioned on the global, with the local, community, family left at the margins.
\end{abstract}

Keywords: peace, communication, Twitter, thematic coding, grounded theory, exploratory research

\section{Introduction}

In 1986, writing about peace studies Johan Galtung said:

'As this complexity moves through history, peaks of joy and troughs of pain are experienced by the human beings populating the system; peace studies are usually concerned more with the avoidance of latter, not how to obtain the former.'

It is what he called the negative and the positive 'side of peace studies' (Galtung, 1986). Why is the above still a relevant quotation? Works in peace research show that the field is still preoccupied with inquiries of how to avoid the pain (Gleditsch et al., 2014a) and not how to obtain the 'peaks of joy.' While over the years, democratic and liberal peace concepts received interest (Buhaug et al., 2014), peace research is still often seen and discussed through the lens of conflict (Gleditsch et al., 2014a; Millar, 2020; Weidmann, 2015). For example, a special issue of the Journal of Peace Research was focused on new communication technologies and what they entail. Yet, the works looked into what they entail in terms of conflict, war, and violence, not peace (Weidmann, 2015). Next, comparing research over the years in two prominent peace journals, Gleditsch et al. (2014b) found that negative peace inquiries increased compared to positive peace. Similarly, discussing the advancement of peace research, Gleditsch et al. (2014a) talked about 'the future of conflict data' and not peace data. Millar (2020) suggests that peace research 'failed to support positive peace' because of the 'field's failure to respond adequately to the evolving character of conflict.' Put differently, often, 
the positive peace research is conflated with the study of conflict. I suggest, however, that this is a misunderstanding.

In turn, I use grounded theory approaches to explore and map peace communication on Twitter among Western research organizations and events. To start, Pidgeon and Henwood (2004) suggest: 'The research question in a grounded theory study is not a statement that identifies the phenomenon to be studied. The problem emerges and questions regarding the problem emerge.' Grounded theory approaches are driven by data. One needs to mindfully disengage from known categories and theories that can drive a precarious data analysis. Therefore, I raise one guiding question for the grounded theory approach: What can we learn about peace by reading tweets? The purposive sample presented below, is built to represent the communication patterns among some of the opinion leaders, experts, and decision-shapers in the West. In turn, the analysis gives insights into what the researchers and practitioners in the field see as important, pressing issues of today.

Social media platforms opened a new space for communication. Audiences that were mainly passive in the old media environment became active actors. Media communication is no longer an elitist tool. Digital space gave new tools for civilians to engage in peace (Kumar \& Semetko, 2018; Livingston, 2015; Rodríguez, 2015). For example, Anup Kumar and Holli A. Semetko (2018) showed how citizens have become involved actors in peace communication between India and Pakistan. Looking at the 2014 Peace March in Moscow, Olena Nikolayenko (2019) showed how peace march supporters and opponents framed and reframed the meanings of calls for a peaceful resolution between Russia and Ukraine. In turn, social media research produced a considerable amount of works focused on social movements and new ways of seeing and theorizing social action (Kumar \& Semetko, 2018; Meraz \& Papacharissi, 2013; Nikolayenko, 2019; Rohman, 2019).

In parallel came the rise of suppression of digital activism (Cai \& Zhou, 2016; Gasser et al., 2011; Lamoureaux \& Sureau, 2019). Yet, it became clear that power relations are changing. Social media restructured power. While digital space still reproduces old power asymmetries, it also opens new spaces for other actors (Richmond, 2020; Tufekci, 2014b; Tufekci, 2014c). For example, Zeynep Tufekci (2013) describes microcelebrity networked activism and tells the story of Bahraini activist Zainab Al-Khawaja to show how digital space alters power relations between citizens and the government.

\section{Public engagement on social media}

Social media has become a popular tool to engage the public and disseminate research (Klar et al., 2020; López Pérez \& Olvera Lobo, 2016). In science communication, public engagement is a popular topic, with two leading thematic directions: engagement approaches and discussion approaches (Davies, 2009; Smallman, 2019; Wilkinson, 2014). Often, however, the focus is on scientists' views and approaches in communicating science or how science communication should be (Chilvers, 2013; Jones, 2014; Llorente et. al., 2019; López-Goñi \& Sánchez-Angulo, 2018; Pieczka \& Escobar, 2013; Selin et. al., 2017; Wilkinson, 
2014). There is still a lack of studies that explore the content of such communication and what it entails (Alcíbar, 2019).

Why explore public engagement content with science on social media? I see two directions that drive this work. First, such communication is directed outward and informs decisions of the public and policymakers (Gropp, 2019; Gayoso et. al., 2018; Noble \& Fulton, 2020). In turn, the content of such communtcation potentially reveals what is projected as important, pressing issues and where the attention of the audience is positioned by the communicator. Second, public engagement content analysis can also be used for inward-directed feedback (Hart \& Nisbet, 2012; Lakoff, 2010). For example, Peters (2021) described potential negative science communication effects and raised the ethical responsibility question that science communicators should consider. In turn, exploring public engagement content quantitatively and qualitatively can give feedback for communicators themselves and give directions for communication planning.

Finally, media effects studies and agenda setting, priming, framing theories are relevant in the context of this study (Scheufele \& Tewksbury, 2007). Yet, such studies focus on the effects on the public rather than the content itself. Therefore, I do not take media effects theories as analytical frameworks, as I do not analyze media effects. I suggest, however, that it is useful to have media effects in mind, when exploring the results of this study.

\section{Methods: Data collection and analysis}

I used purposive sampling to select organizations and events that are focused on peace work and research in the West. Additionally, the selection was partially based on snowball sample, where the sample was increased by searching for contacts between organizations. The sample is not exhaustive and does not indicate that particular excluded organizations were deemed unimportant (e.g., not all organizations have Twitter, some organizations tweet mostly in other languages and not English). Overall, the list represents a community of some of the decisionmakers, experts, and opinion leaders: United States Institute of Peace (USIP), Peace Research Institute Oslo (PRIO), Stockholm International Peace Research Institute (SIPRI), Paris Peace Forum (PPF), Department of Peace and Conflict Research at Uppsala University (UU Peace), Uppsala Conflict Data Program (UCDP), Geneva Peace Week (GPW). The chosen organizations limit the inquiry to a Western perspective and the English language. In part, these limitations reproduce the problematic Western-worldview. Therefore, I discuss the findings in the context of non-Western empirical works and suggest these limitations as a direction for future research.

Twitter API limits its data extraction. These limits affect the representativeness, exhaustiveness, and scope of a sample (Gerlitz \& Rieder, 2013; Tufekci, 2014a). I suggest, however, that purposive sampling results in a relatively small sample compared to big data. I have extracted the available limit $(3,200)$ of tweets in the English language for each organization and event. In my sample, only two selected organizations (SIPRI and USIP) had more than 5,000 tweets in their activity history. The data collection was done with Chorus Tweetcatcher (Brooker, Barnett \& 
Cribbin, 2016) in April and May 2020. The retweets were removed and only direct tweets were used for the final data set. This resulted in a data set of 9,874 tweets in total or the following number of tweets per account: GPW: 665; PPF: 1391; PRIO: 1495; SIPRI: 2821; UCDP: 307; USIP: 2842; UU Peace: 353.

For data analysis, I applied grounded theory approaches and thematic coding with Atlas.ti. I chose grounded theory as it allows me to approach data without predefined categories and theories (Belgrave \& Seide, 2019; Charmaz, 2006; Corbin \& Strauss, 2008, pp. 159-194). There are disagreements if and how researchers should integrate familiarity with the literature when applying grounded theory (Kelle, 2019; Thornberg \& Dunne, 2019). In turn, to strengthen the analytic inquiry, analysis steps were conducted with a general knowledge of the peace literature yet without the familiarity of specific theories that would guide my analysis.

The data set that I compiled, however, is limiting some analytic strengths of grounded theory. Grounded theory is often used to analyze complex social phenomena (Charmaz, 2006, 42-71; Corbin \& Strauss, 2008, pp. 229-247; Saldaña, 2014). Studies that apply grounded theory usually analyze interviews and ethnographic data (Belgrave \& Seide, 2019; Corbin \& Strauss, 2008, pp. 229-247; Kelle, 2019). By contrast, a tweet is a short message, which, in my data set, is communication not among people, but rather an organizational communication directed at a digital audience. In turn, some processes such as power relations can be grasped in limited ways. I argue, however, that Twitter communication represents what the communities that work in the peace field see and promote as important. Therefore, Twitter communication analysis can partially reveal what is seen and projected as current, pressing issues in the field.

Thematic coding can be prone to researcher bias. For example, when focusing on themes, the researcher can lose connection with the context (Friese et al., 2018). I suggest, however, that tweets are short and written in a manner that puts all the context in one tweet. Twitter limits a single tweet to 280 characters. Therefore, the thematic coding of tweets limits the data analysis challenges that can arise with other data sets.

For the analysis process, I do not define communication and look at what emerges from the data instead. On a basic level, however, I see one tweet as one message that exemplifies communication as a data point. Next, what is the analysis process? According to Kathy Charmaz (2006): 'Analytic directions arise from how researchers interact with and interpret their comparisons and emerging analyses rather than from external prescriptions.' In turn, to decide what analysis approach is the best, I did an initial reading of the data set to get to know it. This step revealed that some tweets are not related to peace (e.g., invitations to an event). In turn, the root word peace was autocoded on a sentence level to get a cleaner data set.

The autocoded corpus was then manually coded to establish theme patterns within the data. Codebook is provided in Appendix A. First, in vivo coding was used to capture all the words, phrases or full tweets that exemplify a potential theme (Corbin \& Strauss, 2008, pp. 65-86). In vivo coding means I use raw data text as a 
code label. The coding was done inductively, allowing the themes to emerge from data. Next, in vivo codes were grouped into themes. This process was nonlinear and the codes were reviewed and adjusted through all the analysis stages (Pidgeon \& Henwood, 2004).

This process resulted in a total of 4,274 codes that were grouped into 63 distinct themes. Some themes were developed from in vivo codes (e.g., trust) and some represent a group of codes (e.g., peace), which makes the theme frequency relative to the keywords that constitute it. Therefore, theme frequencies need to be interpreted with caution as a higher frequency does not necessarily translate into a larger or a more salient theme. In general, 63 is a large number of final themes and several themes could be merged. I chose, however, to emphasize themes that otherwise would be concealed. For example, the theme of trust could be grouped under the theme of peace as it emerged as an element of the peace concept. Yet, the choice to leave it as a separate theme indicates how relatively marginal the topic of trust is overall. Finally, a number of themes were selected for further exploration.

In the following section, I present and discuss peace as the main theme, its subthemes, and descriptive results. Subtheme frequencies were visualized using Tableau Public. Detailed frequencies for figures 1, 2, 3, and 4 are provided in Appendix B. Additionally, I used Voyant tools to emphasize, contrast, and visualize keyword frequencies (Sinclair et al., 2013; Sinclair \& Rockwell, 2012). I emphasize that all the sub-themes are tightly connected to the main theme of peace as it is the central concept in my coding approach.

\section{Results and discussion}

A total of 4,274 codes were grouped into 63 themes (Figure 1). I found that some tweets merely mention topics with little context while providing links to further information (e.g., articles). Such additional information was out of scope and not analyzed. Often, Twitter communication is short and does not allow one to grasp the complexity of themes. Therefore, I present and discuss the results with this limitation in mind. Throughout this section, I explicitly indicate if and when a code appears without context.

The most frequent theme in data is an actor. The majority of actors were concrete names of people (e.g., @actorname). Therefore, to fully understand this theme I needed to additionally gather information on all such actors. This stage in the research was not part of the formal analysis. I do, however, argue that the dominance of an @actorname, often followed by organizational affiliation, indicates the dominant power of expert actors. It is what these experts say that is projected to the audience as important. In turn, it is an indication of the overt ways how old power structures are reproduced in the digital space (Richmond, 2020).

Finally, I found that data tell little about what peace is compared to what needs to be done to achieve peace and to avoid conflict or as Galtung (1986) called it, avoiding the 'troughs of pain.' I argue that this finding, ultimately, provides few answers but does raise questions: Are the discussions about what peace is lacking 


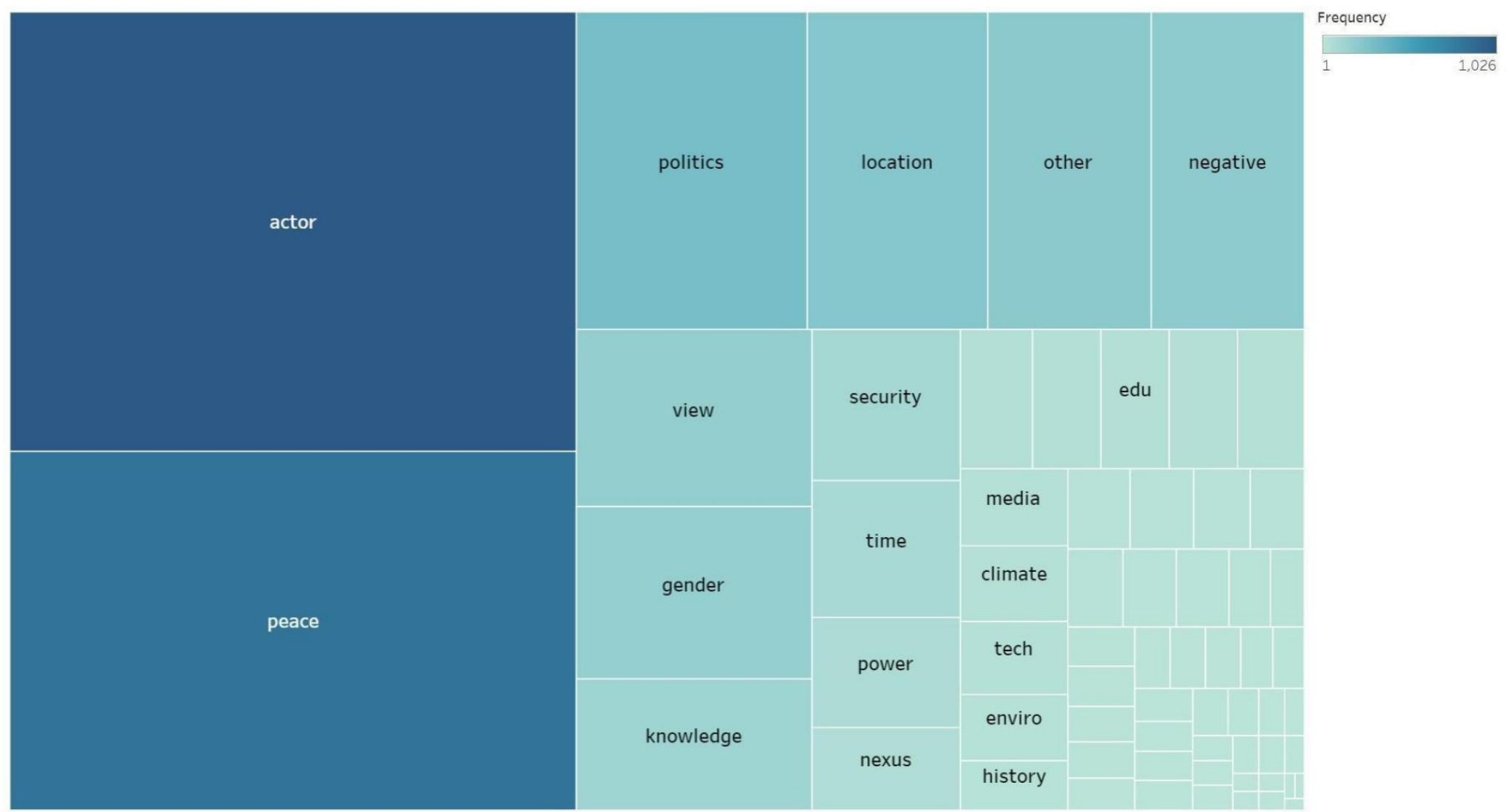

Figure 1. Theme frequencies. 
today and reflect a need to expand on this subject? Does this mean that the meaning of peace still needs to be imagined? Does such communication affect the mindset of the audience and how? In turn, does it have an impact on the peace processes on the ground?

\section{Tweeting about peace}

The peace theme represents a group of distinct sub-themes: a) in vivo codes that capture specific keywords and their context (e.g., peace, peacebuilding, solutions) and b) thematic codes that group thematically identical items (e.g., type of peace, peace-related documents). Figure 2 shows 16 dominant sub-themes by frequency. I argue that this theme structurally represents a core that holds the other themes around it.

A total of 52 codes exemplify what defines peace (with their frequency in the brackets):

1) The conditions needed for peace (24).

2) The indications of what is peace (9).

3) General statements about pace (6).

4) The indications of what peace is not (5).

5) The meaning of peace (5).

6) The questions raised about peace (2).

7) Peace as a reason for something (1).

Next, I look closer into each. Most frequent tweets suggest conditions needed for peace. For example:

'We can't have peace without justice and without the basic and fundamental rights.' (GPW)

'Ultimately it's people who make peace.' (GPW)

'There is no peace without good governance.' (PPF)

'No peace without women!' (PRIO)

The following tweets describe what peace is:

'Peace is made up of all the \#solutions that build a better organization of our planet.' (PPF)

'Peace is made up of all the solutions that reduce international tensions.' (PPF)

'Peace is the common aspiration of mankind.' (PPF)

'Peace as something possible \& practical.' (USIP) 


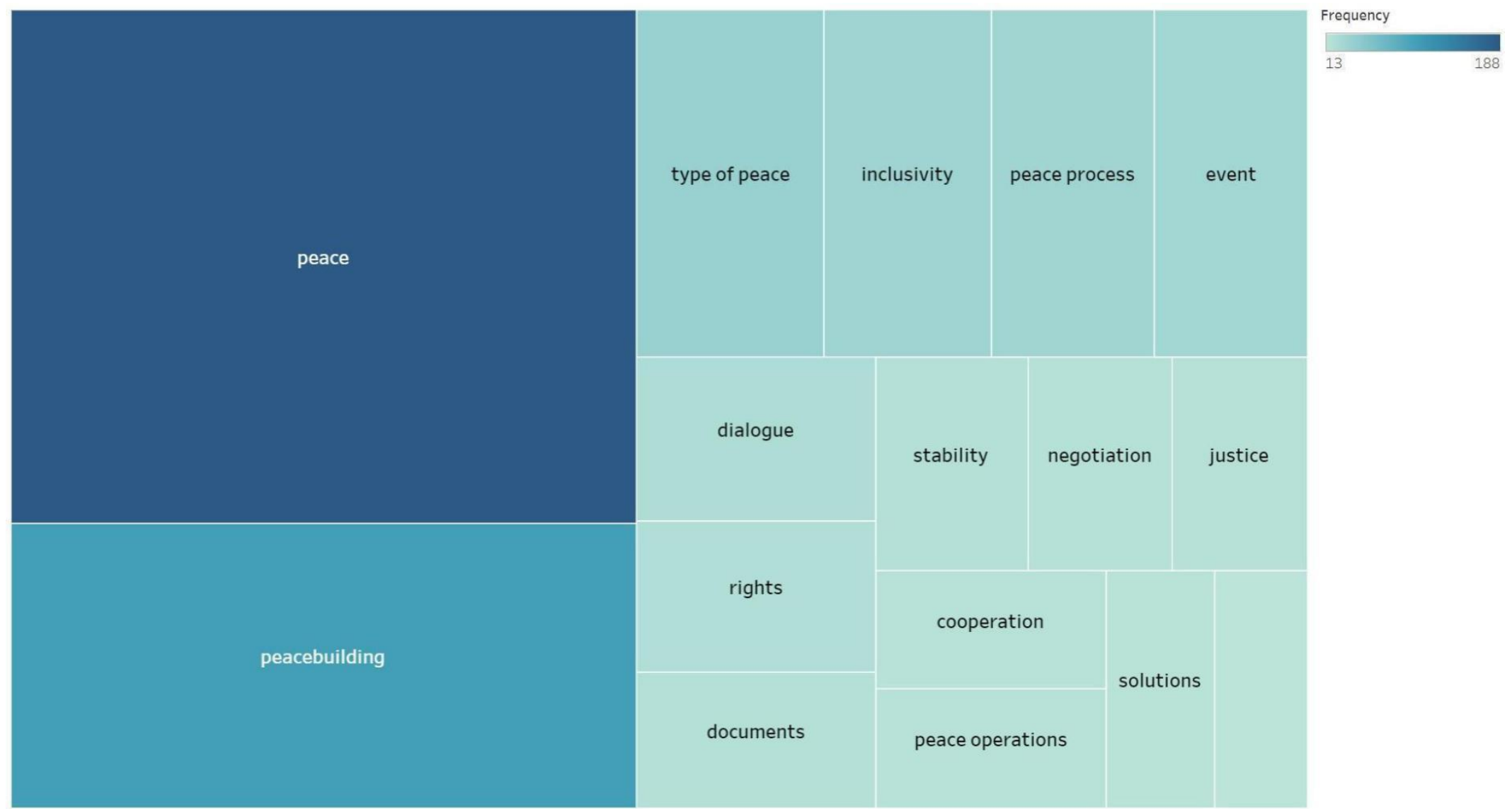

Figure 2. 16 dominant peace theme sub-themes. 
Next are general statements about peace. For example:

'Everybody wants peace.' (USIP)

The following tweets suggest what peace is not:

'Peace is not just the suspension of war.' (PPF)

'Peace does not come with one handshake.' (USIP)

'Peace is not simply the cessation of violence.' (USIP)

Finally, these examples relate to the meaning of peace:

'What does "peace" mean to youth in different contexts?' (GPW)

Looking at the type of peace sub-theme, I found 20 types of peace in the autocoded data set. The frequencies of the types of peace were adjusted using the full data set (Figure 3). While these types of peace have the potential to contribute to the understanding and promotion of peace and its meanings, I was not able to capture such underlying meanings as these types of peace appeared in tweets as phrases without explanation.

The most apparent observation from these findings is the lack of 'peaks of joy' (Galtung, 1986). Similarly, these findings provide little understanding of what is peace. Moreover, I suggest that findings indicate the need to yet imagine the meanings of peace. There is, perhaps, a connection between how peace is communicated on Twitter and the definitions of peace discussed by Davenport et al. (2018). In particular, the communication echoes the theoretical literature where vagueness persists over concrete, tangible components in the definitions of peace (Davenport et al., 2018). This pattern of vagueness emerges in phrases such as 'all the solutions' (PPF), 'common aspiration' (PPF), 'something possible \& practical (USIP), 'everybody wants' (USIP), among others. Similarly, as in peace definitions (Davenport et al., 2018), communication often projects normatives views rather than meaningful and tangible examples. In turn, to further test these initial observations, I explore a number of themes and the context in which they are presented in the following sections. 


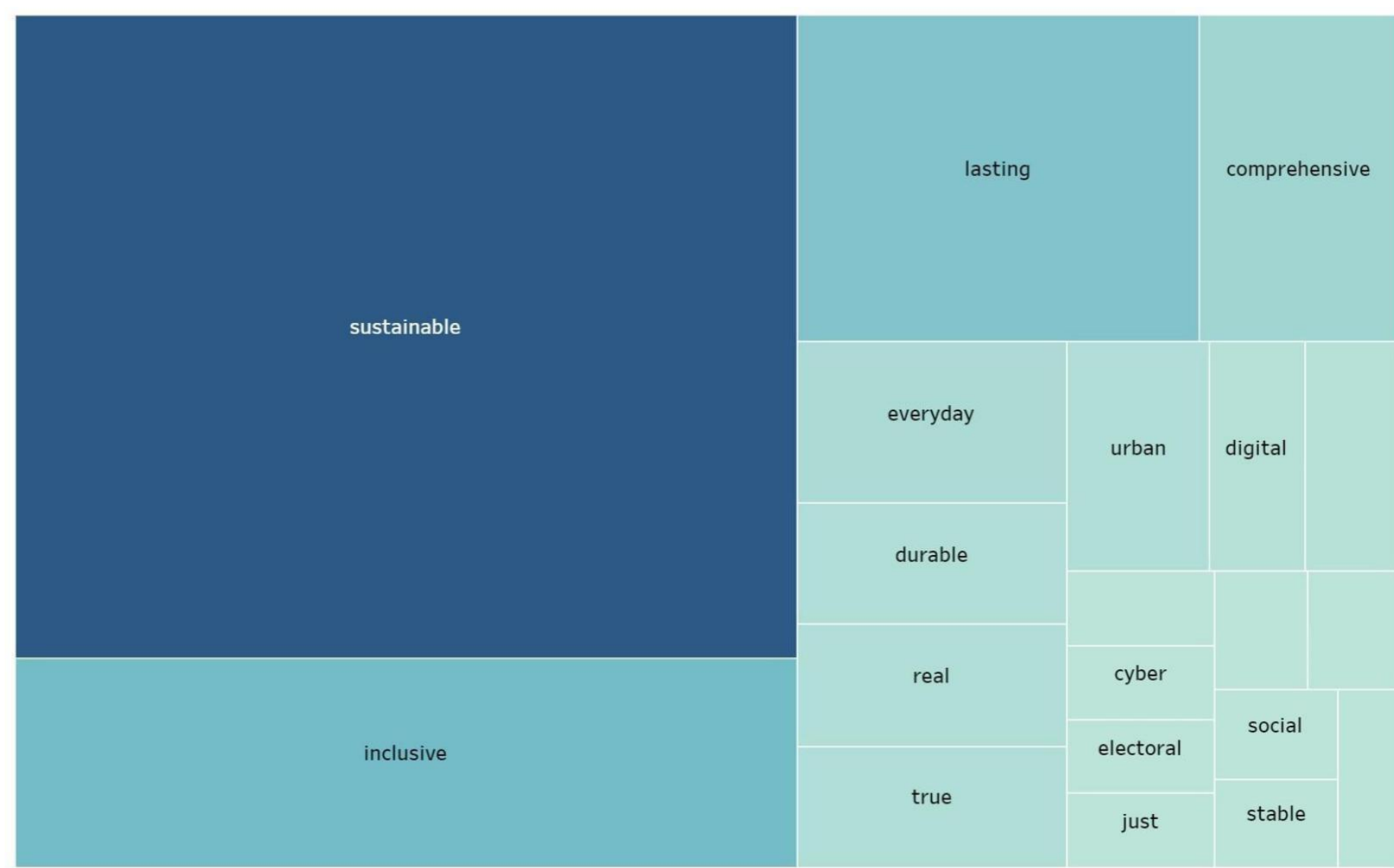

Figure 3. Types of peace in the full data set. 


\section{Women without context}

The topics associated with women were coded 128 times. 39 codes were with the keyword gender. By contrast, the keyword men was coded six times. Codes show women as actors or women in action, include references to documents about women's issues, and talk about the empowerment of women. Yet, only nine codes in total connect women with other topics. For example, one tweet from PPF refers to the problematic context of gender imbalance in software development:

' $90 \%$ of all software are being produced by men, which means that most $\mathrm{Al}$ are just repeating the bias and we don't even know.'

I found 13 instances where the tweets about women indicate reasons why women's participation is important, for example:

'Peace accords by women are $35 \%$ more likely to last $15+$ years. But since 1990 women comprised $2 \%$ of mediators.' (PPF)

'Research from the @UN shows that women only represent about 4\% of negotiators, but when women are able to achieve influence they make peace processes and agreements more effective and sustainable.' (USIP)

The lack of context of why women need to be a part of processes is problematic. For one, such messages do not build meaning and context for the audience. In turn, the message is potentially lost or misunderstood (De Bruijn \& Janssen, 2017; Lakoff, 2010). For example, in the case of Austria, Mayer et al. (2014) showed how right-wing populists reframe gender agenda and gender equality ideas as a lack of 'common sense' or something that is against 'traditional (family) values.' In the context of my findings, I argue that the lack of salient context can leave space for reframing that is negative and can discredit the efforts and the goals of women's inclusion.

Additionally, the lack of context is problematic when disseminating the message of what the actual inclusion of the gender question is. Subsequently, countries struggle to meaningfully implement the ideas of gender politics and to translate international agendas into local action. For example, looking at peacebuilding efforts in Uganda, Simone Datzberger and Marielle L.J.Le Mat (2018) suggest:

'Gender initiatives in the country seem to have started as an 'add women and stir approach', thereby fortifying an 'add another policy and stir' approach in relation to gender - and recently also peacebuilding. In this process, policies appear to meet the standards of the international community as set out in the MDGs (Millennium Development Goals) or SDGs (Sustainable Development Goals). Yet according to our analysis, they fail to address root causes of structural inequalities in Ugandan society.'

Similarly, exploring Women, Peace, Security agenda in Finnish foreign policy, Jauhola (2016) shows how, in the case of Aceh, Indonesia, 'Acehnese women's experiences of the peace negotiation process, the peace settlement (MoU) and the first decade of post-conflict reconstruction shout out loud as abjected and thus invisible in this brand development.' In another case, Pepper (2018) reveals the gap between the rhetoric of women's inclusion and actual implementation: 'A 
rhetoric of support for women's inclusion and UNSCR 1325 is present in Myanmar, but it has little traction when it comes to implementation.'

The above gap between agendas and practice is not unique to the local level cases. Exploring UN peacekeeping, Lesley J. Pruitt (2016) interviewed UN staff about the 'all-female formed police unit (FFPU)' in India and concluded:

'The interviews cited here highlight that many UN officials' understandings of the FFPU reflect a suspicion of "gender segregation" in all forms (though in practice applied only to all-female spaces or policies), with little discussion of whether or how it may affect theory, policy, or practice positively or negatively.'

So, what does it mean when the gender theme, as I found, is often discussed as a separate theme and not an integral part of the dialogue about peace or conflict? For example, in the data set, the reintegration of ex-combatants does not appear as a topic that integrates gender. Consequently, what are the implications? Siphokazi Magadla (2015) discusses how definitions of what a military veteran is, exclude some women that were in combatant roles. Subsequently, such women did not benefit from the demobilization processes and the 'pension, housing, health and education benefits that are due to veterans' (Magadla, 2015).

I found a similar absence of gender integration in other themes, for example, that involving the marginal health theme discussed below. What is the role of reproductive health in conflict and peace? Maternal health only appears in three tweets within the full data set. Similarly, the theme of youth does not tell us if girls can participate in social youth movements in the same way that boys can. Are there obstacles in youth participation based on gender? Additionally, the finding that men were coded six times indicates that there is an overall lack of understanding of the context of gender issues. In sum, I argue that my findings confirm the 'add women and stir approach' discussed by Simone Datzberger and Marielle L.J.Le Mat (2018). Echoing the ideas of ethical responsibilities of science communicators raised by Peters (2021), I suggest that these findings can be used to assess if the current communication about gender has potential negative effects and to improve it.

Focusing on global and missing the local

172 codes indicate various levels of view, in which matters are presented. I found that overall the dominant level of tweets is global (e.g., world, international, planet), with 95 codes in total. By contrast, micro-level - individual, family, and home were coded only 14 times. In other words, communication tends to focus on broad, frequently vague matters and avoids the messier, but critical details that a highresolution analysis of local peace processes requires. This finding is in line with the explorations of peace definitions by Davenport et al. (2018), who found the dominance of definitions that look at peace on the interstate level, with individual and community levels as marginal. In turn, I suggest that my findings indicate a potential connection between the definitions of peace and the communication of peace. That is, the definitions might underpin and shape the attention to the global 
level of analysis, sidelining the local meanings and what we observe on Twitter is the effect.

Additionally, I found one tweet that critically addresses the tendency to focus on the global south:

'For the last quarter of a century, peacebuilding as an activity has been problematically looking southward.' (GPW)

Finally, I found one tweet that addresses peace in Europe:

'This year at \#GPW19, a lot of conversations centered on the importance of building peace right here in Europe.' (GPW)

Perhaps, unsurprisingly these findings echo the common levels of analysis in peace research, where the most common is the interstate level and the individual and community levels are sparse (Davenport et al., 2018). This theme intersects with other themes. Looking back at the marginal codes that would indicate the context in the gender theme, I identify a need to direct the level of view to what happens on the ground. That is, peace-related processes need to be contextsensitive. A global view fails to capture the complexities of the themes discussed throughout this work, for example, family, life, and health.

\section{Power and peace}

With 67 codes in total, power emerges as a relatively vague theme. The most common associated topic within it is empowerment, followed by political power and civil society power.

I found one tweet about South power:

'The "Network of Southern Think Tanks" is a collaborative academic forum for the South by the South which aims to generating, systemating, consolidating and sharing knowledge on South-South co-operation approaches to international development. \#standforpeace \#PeaceDay' (PPF)

Next, one tweet mentions the power of artificial intelligence (AI):

'It's \#peaceday, and we want to talk about the role of Al! \#AI is changing how we perceive peace, war \& power. We are ready to tackle all this at \#PPF2019, and we want to know what you think: what role can Al play for peace? \#Alforpeace \#solutionsforpeace' (PPF)

One tweet raises the need for improved power analysis:

'Devising indicators capable of analysing power dynamics in peace processes would be a valuable contribution to the field' (SIPRI)

Finally, one tweet exemplifies the personal power a community member feels:

'Politicians are not the only ones who can bring peace. I can be a peacemaker. I can bring peace to myself, my family, my community.' (USIP)

In the full data set, empowerment emerged as an ambiguous goal (29 out of 35 instances) directed at people on the ground (e.g., citizens, communities, women, 
girls). This ambiguity homogenizes local populations and implies that people on the ground are powerless. This powerlessness is presented as something that can be addressed and tackled by a powerful international actor. I argue that these findings indicate a failure to acknowledge the complexities of a local context and misrepresent the reality on the ground. Unfortunately, it is a known issue, when an international actor is creating a subordinate relationship with the local civil society and the local knowledge (Shepherd, 2015).

Similar to what Richmond (2020) described, this finding of the rhetoric of empowerment shows the obvious way of how old power structures are reproduced in the digital space. On social media like in other media, international actors use the same rhetoric to talk about their work on the ground. While it might be unintentional, this rhetoric enables the old ways of seeing people on the ground as the receiving party in need, without agency and international actors as the giving party that knows what is needed (Shepherd, 2015).

Additionally, I argue that power needs more overt and varied discussions. On many levels and among various actors, power often plays a crucial role. For example, local cases show that agreements, which take power into account, are more successful. In Nigeria, power-sharing eases interreligious conflict (Bunte \& Vinson, 2016). Looking at power-sharing settlements and conflict termination Chelsea Johnson (2020) shows that, 'when both inclusive and diffusive subtypes are included in a settlement, the likelihood of dyadic conflict termination increases to 92.31\%.' On the international level, the power of international organizations is problematic. For example, in the case of the United Nations, the relationship puts the local community and 'civil society in a subordinate relationship with the UN and does function to reaffirm the supremacy of UN/international knowledge over civil society/local knowledge' (Shepherd, 2015). In sum, the findings indicate that the current communication on Twitter downplays the role of power in the context of peace.

\section{Technology for peace}

While technology was coded 33 times in total, only 16 codes exemplify technology in the context of peace. Other codes appear in tweets that merely mention technology or related keywords (e.g., cyber, digital). Five tweets present technology as an engagement and peacebuilding tool. For example:

'Creative use of technology that enables Afghan women to engage in activism, such as fostering online communities for peacebuilding discussions, can encourage greater participation in peace processes.' (USIP)

I argue that these findings indicate the need for a more diverse attention to technology in the context of peace communication. For example, in the case of asylum seekers, Ustek-Spilda and Alastalo (2020) show the dangers of technology becoming the automated decision maker. Technology is assumed as a bias free tool. Yet, it fails to take personal circumstances into account (Alastalo, 2020). In turn, do algorithms stand in the way of people who search for peace? Does technology get to decide if an asylum seeker is worthy of a peaceful life? These and other questions are important in building the public understanding of peace 
research. At the same time, the lack of such discussions indicates that the field itself might be leaving pressing issues and novel topics at the margins.

Technology became an important tool in various processes. For example, it is an important tool in activism. Yet, some governments use suppression of digital political activism (Cai \& Zhou, 2016; Gasser et al., 2011; Lamoureaux \& Sureau, 2019). Looking at the role of technology in the humanitarian field, Madianou et al. (2016) showed how it can impede accountability. In turn, what do these examples mean in the context of peace and peacebuilding? For example, when there is an effort to enable women as digital peace activists, if and in what context it puts them in danger? Can technology limit or eliminate such danger? These are just a few questions that need to be raised in the intersections of technology and peace.

\section{Media in peace processes}

Overall, the keyword media was coded 34 times. I found tweets that exemplify the positive role of media and social media in peace processes. By contrast, I found no tweets that mention the negative role of the media.

Today, social media is a tool used by a variety of actors. For example, David Shim and Frank A. Stengel (2017) analyze the use of Facebook by the German military mission in Afghanistan. Nicole Sunday Grove (2019) outlined the use of social media to crowdfund, support, or even recruit combatants against ISIS. Similarly, social media is a powerful tool that can give a voice to the voiceless and help record war crimes. It can also delete such voices and war crimes. Recently it became clear that the cost of social media content moderation can be very high. While content moderation was not ill-intended, the content that was deleted in the past was crucial in transitions from war to peace and efforts to bring about justice (Banchik, 2020; Hamilton, 2020; Gregory, 2019). In turn, when social media platforms moderate the negative aspects of the content, such as incitement (Gregory, 2019), the loss of evidence could and should be avoided.

The theme of media is tightly connected to the theme of accountability. For example, Maria Armoudian and Barry Milne (2019) show a connection between news media messaging and violence in Northern Ireland. It raises complex questions of complicity and the contribution of media coverage to violence. Yet, who is accountable? Similarly, technology is an important part of the media theme and the discussion of both themes should be seen as interconnected. Media, however, emerged only as a marginal theme in the data set.

\section{Peace without health}

I have coded 21 tweets related to health. Overall, only four tweets address postconflict trauma. For example:

'Overcoming collective traumas is key to sustainable peace in post-conflict societies. Discuss how we can better support mental wellbeing of affected groups with key actors and stakeholders at the Paris Peace Forum \#standforpeace \#WorldMentalHealthDay' (PPF) 
'Research from @who estimates that over 2 million Afghans suffer from depression and anxiety. How can grassroots peace efforts address the shared trauma of a generation that has known nothing but war and violence?' (USIP)

I found only three tweets that discuss the connection between health and peace. For example:

'The "Peacebuilding through Health" project intends to support vulnerable populations at each stage of the conflict management cycle and to design health services that contribute to sustaining peace. @who \#standforpeace \#PeaceDay' (PPF)

'In the immediate aftermath of conflict, what are some of the short-term public health risks that can derail a peace process, and what can be done to mitigate them?' (USIP)

In the full (not the autocoded) data set, the topic of mental health appears only four times. These findings are alarming in the context of the systematic review of mental disorders in conflict settings by Charlson et al. (2019), who 'estimated that at any point in time about $9 \%$ of the conflict-affected population has moderate to severe mental disorders.' While it is an oversimplification to suggest that Twitter communication reflects the work of organizations overall, I argue that the overt lack of public discussions about the impact of conflict on mental health, reflected in the data set, indicates an existing pattern.

The intersections between peace and health play a crucial role in transitions from conflict to peace (Abuelaish et al., 2020; Burnham, 2020; Idrobo et. al, 2018; Shimony et al., 2019). Regarding female health, Sara E. Davies and Sophie Harman (2020) argue that reproductive health is 'a matter of international peace and security.' As a result, my findings raise a question, as to whether there is a lack of diversity in the peace-related expertise in the area of public health. In sum, assuming that such issues are neglected systemically, how might more diverse expertise address the problematic dynamics of work on the ground (Cox \& Webb, 2015; Gartrell \& Soldatic, 2016; Montiel, 2018)?

\section{Daily life}

Daily lives emerged as a marginal theme with 9 codes in total:

'New SIPRI Policy Paper highlights 5 key areas to help build \#peace in the everyday lives of Kirkukis.' (SIPRI)

'Communities across Colombia primarily care about the human impact of the peace accords on their daily lives, @CristoBustos says. \#DefendamosLaPaz \#ColombiaPeaceForum' (USIP)

These findings are more meaningful and important in the context of Pamina Firchow's (2018) work. Professor Firchow advances present understanding about what aspects of peace-related interventions lead to success or failure. In particular, she considers how peace-related interventions require meaningful community 
participation. For example, effective economic development can lead to perceptions of reduced security on a personal level (Firchow, 2018). While the importance of community perceptions of peace in their daily life might seem to be self-evident, my findings indicate that attention to daily life emerges as marginal.

\section{Accountability}

In this theme, two keywords were combined: accountability and responsibility. The theme is marginal, with eight codes in total. Only two tweets address accountability by international organizations to local populations:

'Now at the @TheGCSP for the UN Peacekeeping: Greater Accountability Toward the Local Population in the Era of \#MeeToo and \#AidToo with @KevinCChang@ @DrMelOB @sharanyakkn@Aidsfreeworld n\#GCSPDiscussion \#GVAPW' (GPW)

'Don't burden the local actors with proposal writing. There is too much pressure on the locals; local peacebuilders are being forced to be accountable to the international donors rather than to the local community. Abdulhamid Qabbani, Jouri Research and Consulting \#GPW19' (GPW)

The lack of attention to accountability in the field is worrying. Unfortunately, the question of accountability of peace-related processes appears to still be a relatively new topic in the field. For example, Gisela Hirschmann (2019) showed how vertical accountability evolved in the UN bureaucracy. And while businesses take an active role in peace and conflict (Miklian \& Medina Bickel, 2020), the question of their accountability is almost absent with any evaluation limited to the general concept of corporate social responsibility (Rettberg, 2016). Besides actor accountability, there are other pressing issues in the context of accountability. For example, technology can impede accountability on the ground (Madianou et al., 2016). In sum, I argue that accountability should not be a marginal theme in peace-related communication. It should be seen as an integral part of other themes discussed here. Accountability should be seen as an integral part of peace processes, not a side note.

\section{Peace and trust}

Trust is a common component of peace (Davenport et al., 2018). Yet, trust was coded in data only seven times. Six tweets address building and rebuilding trust. For example:

'Our latest report outlines how trust-building with religious leaders and networks could be key to peacebuilding in the region.' (USIP)

Trust is a common element in the definitions of peace (Davenport et al., 2018). It also plays a crucial role on the ground. Trust is a part of the reintegration success of ex-combatants (Kilroy \& Basini, 2018). Post-conflict economic aid can have effects on trust and distrust (Byrne et al., 2009). Pui-Hang Wong (2016) described political trust-building after a civil war. Similarly, Isak Svensson and Karen Brounéus (2013) looked at the role of dialogue on inter-ethnic trust in peacebuilding. By contrast, mistrust can lead to the dehumanization of the other 
(Montiel et al., 2019). Additionally, these examples show that trust often intersects with other aspects of peace-related processes. Yet, the data show that trust plays a marginal role in peace communication.

\section{Family and peace}

I found the theme of family to be marginal in peace-related communication. Family and peace are only discussed in four tweets within the data set. For example:

'Despite differences in age, education and vocation, Afghan women at a recent workshop were united in their desire to work for peace and shared a common vision for their country and concern for their family's futures.' (USIP)

While this theme could be defined as similar to the life theme, I did not group these to emphasize the potential role of a family as an important component of peace and contributor to post-conflict stability. Family is the first to experience grief in a conflict when a member is lost and the first that can support the peace process from the bottom (Weder et al., 2010). Based on these findings, family, as an important component of peace processes, is overlooked.

Language for peace

There were four codes in the autocoded data set marking the language theme. One tweet shows that peacebuilding has its language:

'Our extensive \#PeaceTerms glossary provides concise definitions of hundreds of terms used in the field of \#peacebuilding, including more than 60 new or revised terms. Now also available in Arabic, French, and Spanish.' (USIP)

Two tweets point at the intersection between language and radicalization and reintegration:

'On our latest \#OnPeace podcast, our Leanne Erdberg says she thinks "language has a really important role to play" in reintegrating those disengaging from violent extremism and building peace long-term.' (USIP)

In Figure 4, I show the word frequency contrast between root words peace (in green) and language (in purple). Each line represents the full data set for a given organization or event. The lines were divided into 100 segment granularity. The bubble size indicates the keyword frequency per segment, where a larger bubble indicates a higher frequency. The total number of both keywords per data set are indicated at the end of each line (detailed in Appendix B). 
PRIo tweets Paris PF tweets

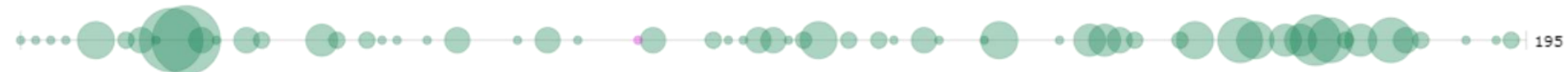

SIPRI tweets

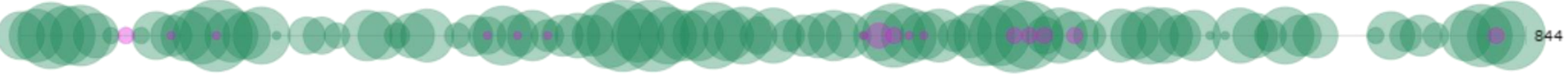

UCDP tweets

usip tweets
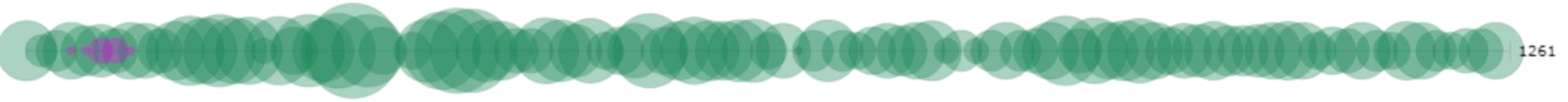

Figure 4. Frequencies of root words peace (in green) and language (in purple). 
Language plays a role in peacebuilding (Charalambous et al., 2019), in documents (Brok, 2016; Hudson, 2017), conflict (Belavadi \& Hogg, 2016; Medeiros, 2017; Tesseur, 2019), and communication disorders (Battle, 2015), among others. Translators without Borders (2019) found that language barriers can limit refugees' access to services such as health, education, and humanitarian assistance. So, why is language such a marginal theme in the data set? Similarly, I argue that language cannot be discussed without acknowledging its role in other themes. As discussed earlier, some failures in themes such as gender, technology, and media can be ascribed to the way of how language is used. The marginality of the language theme raises questions about if and why some expertise in the peace field appears marginal and what are the likely consequences.

\section{Conclusions}

While sustainable peace is the main type of peace in data, the themes that presumably contribute to it - health, accountability, trust, and transparency, among others - are relatively marginal. This worrying trend is amplified by another finding - the dominant level of view that is focused on the global with little attention to the local. Next, while gender is among the dominant themes, there is a lack of meaningful integration of gender in other themes such as health. Data show that the communication lacks insights about concepts that play a central role in peace, such as families, who presumably are the direct benefactors of peace work. I argue that these findings might indicate a shortage of diversity in expertise within the field. Also, it offers a partial insight into the potential causes for some of the failures in global peace initiatives. I suggest that this exploratory study makes a valuable contribution to pinpoint some dimensions of the present peace communication in the digital space.

On a larger scale, the erosion of democratic fabric in the West - the democratic backsliding (Cianetti et al., 2018; Vachudova, 2020) - and the lack of domestic peace in the US and EU due to populist rhetoric (Araujo et al., 2017; Sehl et al., 2020) shows the need to expand the way peace is projected in the digital age of communication. What is peace in the context of suppression of digital activism (Gasser et al., 2011; Lamoureaux \& Sureau, 2019)? How is technology changing democracy and the related discourse (Dubois \& McKelvey, 2019)?

I suggest a few directions for future research. First, there is a need to study and compare the non-English language peace communication in the digital space. Second, an inquiry into the audience of digital peace communication can reveal how such communication shapes the mind and the behavior of the audience. Third, what is the role of visual digital peace communication? Fourth, while I coded locations that are mentioned in the tweets, additional data collection was needed to show how tweets map locations and what it entails. For example, what does it entail in terms of power relations? Similarly, the most frequent code of actors was not analyzed as the profile of many of the actors mentioned (e.g., @actorname) was not reflected in the tweets. Additional data collection was needed to analyze the actors, their roles, and their connections within and among the selected organizations and events. I argue that such inquiries would offer important insights, 
for example, regarding actor networks, power relations, and the issues surrounding the Western expertise (Alejandro, 2017; Aydınlı \& Biltekin, 2018).

To conclude, I used Twitter communication as a lens to explore what experts communicate as the pressing issues in the field today. Discussing the findings in the context of empirical research, I suggested that these findings, in part, indicate how communication is interlinked with the limited scope of peace definitions as discussed by Davenport, Melander, and Regan (2018). For example, I found the focus to be on the global with limited attention to the local level. Additionally, communication echoes empirical research, which is focused on avoidance of conflict as opposed to the efforts to understand peace and its meanings. Finally, in the context of communication research, findings show some of the gaps and give potential directions for a better-planned communication (De Bruijn \& Janssen, 2017; Elving \& Postma, 2017; Lakoff, 2010). 


\section{References}

Abuelaish, Izzeldin, Michael S. Goodstadt, and Rim Mouhaffel. "Interdependence between health and peace: a call for a new paradigm." Health promotion international 35, no. 6 (2020): 1590-1600.

Alcíbar, Miguel. "Science communication on social media: Current trends, future challenges." In The Routledge Handbook of Language and Science, pp. 385-397. Routledge, 2019.

Alejandro, Audrey. "The Narrative of Academic Dominance: How to Overcome Performing the 'Core-Periphery' Divide." International Studies Review 19 (2017): 300-04.

Araujo, Erin, Federico Ferretti, Anthony Ince, Kelvin Mason, Joshua Mullenite, J. M. Pickerill, Toby Rollo, and Richard J. White. "Beyond Electoralism: Reflections on anarchy, populism, and the crisis of electoral politics." ACME: An International EJournal for Critical Geographies 16, no. 4 (2017): 607-642.

Armoudian, Maria, and Barry Milne. "The politics of blame: Mass media messages and political violence during peace negotiations." Journalism (2019): 1464884919860280.

Aydınlı, Ersel, and Gonca Biltekin. "Widening the World of IR: A typology of homegrown theorizing." All Azimuth: A Journal of Foreign Policy and Peace 7, no. 1 (2018): 45-68.

Banchik, Anna Veronica. "Disappearing acts: Content moderation and emergent practices to preserve at-risk human rights-related content." New Media \& Society (2020): 1461444820912724.

Battle, Dolores E. "Persons with communication disabilities in natural disasters, war, and/or conflict." Communication Disorders Quarterly 36, no. 4 (2015): 231-240.

Belavadi, Sucharita, and Michael A. Hogg. "Conflict between ethnolinguistic groups: Language traitors, language loyalists, and the influence of uncertainty." Journal of Language and Social Psychology 35, no. 4 (2016): 446-457.

Belgrave, L., and Kapriskie Seide. "Coding for grounded theory." The SAGE handbook of current developments in grounded theory (2019): 167-185.

Brok, Johanne Oline Storgaard. "Human rights language and its absence in UN development visions. A discursive examination of the 2015 United Nations Sustainable Development Agenda and the character of human rights language." Provocatio. Journal of Human Rights 2 (2016).

Brooker, Phillip, Julie Barnett, and Timothy Cribbin. "Doing social media analytics." Big Data \& Society 3, no. 2 (2016): 2053951716658060. 
Buhaug, Halvard, Jack S. Levy, and Henrik Urdal. "50 years of peace research: An introduction to the Journal of Peace Research anniversary special issue." Journal of Peace Research 51, no. 2 (2014): 139-144.

Bunte, Jonas B., and Laura Thaut Vinson. "Local power-sharing institutions and interreligious violence in Nigeria." Journal of peace research 53, no. 1 (2016): 4965.

Burnham, Gilbert. "Peace and health in Afghanistan." Lancet 395 (2020): 670-71.

Byrne, Sean, Olga Skarlato, Eyob Fissuh, and Cynthia Irvin. "Building trust and goodwill in Northern Ireland and the Border Counties: the impact of economic aid on the peace process." Irish Political Studies 24, no. 3 (2009): 337-363.

Cai, Yongshun, and Titi Zhou. "New information communication technologies and social protest in China: Information as common knowledge." Asian Survey 56, no. 4 (2016): 731-753.

Charalambous, Constadina, Panayiota Charalambous, and Ben Rampton. "International relations, sociolinguistics and the 'everyday': a linguistic ethnography of peace-building through language education." Peacebuilding (2021): 1-22.

Charlson, Fiona, Mark van Ommeren, Abraham Flaxman, Joseph Cornett, Harvey Whiteford, and Shekhar Saxena. "New WHO prevalence estimates of mental disorders in conflict settings: a systematic review and meta-analysis." The Lancet 394, no. 10194 (2019): 240-248.

Charmaz, Kathy. Constructing grounded theory: A practical guide through qualitative analysis. sage, (2006): 42-71.

Cianetti, Licia, James Dawson, and Seán Hanley. "Rethinking "democratic backsliding" in Central and Eastern Europe-looking beyond Hungary and Poland." (2018): 243-256.

Chilvers, Jason. "Reflexive engagement? Actors, learning, and reflexivity in public dialogue on science and technology." Science Communication 35, no. 3 (2013): 283-310.

Corbin, Juliet, and Anselm Strauss. "Strategies for qualitative data analysis." Basics of Qualitative Research. Techniques and procedures for developing grounded theory (2008): 3 .

Cox, Nigel, and Lucy Webb. "Poles apart: does the export of mental health expertise from the Global North to the Global South represent a neutral relocation of knowledge and practice?." Sociology of Health \& IIIness 37, no. 5 (2015): 683697.

Datzberger, Simone, and Marielle LJ Le Mat. "Just add women and stir?: Education, gender and peacebuilding in Uganda." International Journal of Educational Development 59 (2018): 61-69. 
Davenport, Christian, Erik Melander, and Patrick M. Regan. The peace continuum: what it is and how to study it. Oxford University Press, 2018: 35-78

Davies, Sara E., and Sophie Harman. "Securing Reproductive Health: A Matter of International Peace and Security." International Studies Quarterly 64, no. 2 (2020): 277-284.

Dubois, Elizabeth, and Fenwick McKelvey. "Political Bots: Disrupting Canada's Democracy." Canadian Journal of Communication 44, no. 2 (2019).

Firchow, Pamina. Reclaiming everyday peace: Local voices in measurement and evaluation after war. Cambridge University Press, 2018: 128-146.

Friese, Susanne, Jacks Soratto, and Denise Pires. "Carrying out a computer-aided thematic content analysis with ATLAS. ti." (2018).

Galtung, Johan. "Peace theory: An introduction." World Encyclopedia of Peace, (1986): 251-260.

Gartrell, Alexandra, and Karen Soldatic. "Rural women with disabilities in postconflict zones: the forgotten sisters of Australia's disability-inclusive development." Third World Thematics: A TWQ Journal 1, no. 3 (2016): 370-381.

Gasser, Urs, Rebekah Heacock Jones, Robert Faris, Hal Roberts, and Ethan Zuckerman. "Online Security in the Middle East and North Africa: A Survey of Perceptions, Knowledge and Practice." Berkman Center Research Publication 2011-04 (2011).

Gayoso, Alejandro Soler, Alexander Asinas Michelson, Amanda Wylie Moulaison, and Zachary James Weiland. "Improving Science Communication in Wellington: An analysis of public knowledge of sea level rise in the Central Business District of Wellington, New Zealand." (2018).

Gerlitz, Carolin, and Bernhard Rieder. "Mining one percent of Twitter: Collections, baselines, sampling." M/C Journal 16, no. 2 (2013).

Gleditsch, Kristian Skrede, Nils W. Metternich, and Andrea Ruggeri. "Data and progress in peace and conflict research." Journal of Peace Research 51, no. 2 (2014): 301-314.

Gleditsch, Nils Petter, Jonas Nordkvelle, and Håvard Strand. "Peace research-Just the study of war?." Journal of Peace Research 51, no. 2 (2014): 145-158.

Gorsevski, Ellen W. "Nonviolent theory on communication: The implications for theorizing a nonviolent rhetoric." Peace \& Change 24, no. 4 (1999): 445-475.

Gregory, Sam. "Cameras everywhere revisited: how digital technologies and social media aid and inhibit human rights documentation and advocacy." Journal of Human Rights Practice 11, no. 2 (2019): 373-392. 
Gropp, Robert E. "Interdisciplinarity for Impact: Science Communication." (2019): 099-099.

Grove, Nicole Sunday. "Weapons of mass participation: Social media, violence entrepreneurs, and the politics of crowdfunding for war." European journal of international relations 25, no. 1 (2019): 86-107.

Hamilton, Rebecca J. "Social Media Platforms in International Criminal Investigations." Case W. Res. J. Int'l L. 52 (2020): 213.

Hart, P. Sol, and Erik C. Nisbet. "Boomerang effects in science communication: How motivated reasoning and identity cues amplify opinion polarization about climate mitigation policies." Communication research 39, no. 6 (2012): 701-723.

Hirschmann, Gisela. "Cooperating with evil? Accountability in peace operations and the evolution of the United Nations Human Rights Due Diligence Policy." Cooperation and conflict 55, no. 1 (2020): 22-40.

Hudson, Heidi. "The Power of Mixed Messages: Women, Peace, and Security Language in National Action Plans from Africa." Africa Spectrum 52, no. 3 (2017): 3-29.

Idrobo, Fabio, Philipp Hessel, Arturo Harker, Sara Evans-Lacko, and Mauricio Avendaño. "Mental health of victims and ex-FARC members: a challenge for the peace process in Colombia." The Lancet Psychiatry 5, no. 6 (2018): 467-468.

Jauhola, Marjaana. "Decolonizing branded peacebuilding: abjected women talk back to the Finnish Women, Peace and Security agenda." International Affairs 92, no. 2 (2016): 333-351.

Johnson, Chelsea. "Power-sharing, conflict resolution, and the logic of pre-emptive defection." Journal of Peace Research (2020): 0022343320924699.

Jones, Richard AL. "Reflecting on public engagement and science policy." Public Understanding of Science 23, no. 1 (2014): 27-31.

Kelle, Udo. "The status of theories and models in grounded theory." The Sage handbook of current developments in grounded theory (2019): 68-88.

Kilroy, Walt, and Helen SA Basini. "Social capital made explicit: The role of norms, networks, and trust in reintegrating ex-combatants and peacebuilding in Liberia." International Peacekeeping 25, no. 3 (2018): 349-372.

Klar, Samara, Yanna Krupnikov, John Barry Ryan, Kathleen Searles, and Yotam Shmargad. "Using social media to promote academic research: Identifying the benefits of twitter for sharing academic work." PloS one 15, no. 4 (2020): e0229446.

Kumar, Anup, and Holli A. Semetko. "Peace communication in cross-border media flows." Journal of Communication 68, no. 3 (2018): 612-635. 
Kuusisto, Riikka. "Framing the wars in the Gulf and in Bosnia: The rhetorical definitions of the Western power leaders in action." Journal of Peace Research 35 , no. 5 (1998): 603-620.

Lamoureaux, Siri, and Timm Sureau. "Knowledge and legitimacy: the fragility of digital mobilisation in Sudan." Journal of Eastern African Studies 13, no. 1 (2019): 35-53.

Livingston, Steven. "Digital technology and peace." In Communication and Peace, pp. 192-203. Routledge, 2015.

Llorente, Carolina, Gema Revuelta, Mar Carrió, and Miquel Porta. "Scientists' opinions and attitudes towards citizens' understanding of science and their role in public engagement activities." PloS one 14, no. 11 (2019): e0224262.

López-Goñi, Ignacio, and Manuel Sánchez-Angulo. "Social networks as a tool for science communication and public engagement: focus on Twitter." FEMS Microbiology letters 365, no. 2 (2018): fnx246.

López-Pérez, Lourdes, and María Dolores Olvera-Lobo. "Social Media as Channels for the Public Communication of Science: The Case of Spanish Research Centers and Public Universities." In Facets of Facebook, pp. 241-264. De Gruyter Saur, 2016.

Loyle, Cyanne E., and Samuel E. Bestvater. "\# rebel: Rebel communication strategies in the age of social media." Conflict Management and Peace Science 36, no. 6 (2019): 570-590.

Madianou, Mirca, Jonathan Corpus Ong, Liezel Longboan, and Jayeel S. Cornelio. "The appearance of accountability: Communication technologies and power asymmetries in humanitarian aid and disaster recovery." Journal of Communication 66, no. 6 (2016): 960-981.

Magadla, Siphokazi. "Women combatants and the liberation movements in South Africa: Guerrilla girls, combative mothers and the in-betweeners." African Security Review 24, no. 4 (2015): 390-402.

Matveeva, Anna. "Conflict cure or curse? Information and communication technologies in Kyrgyzstan." New technology and the prevention of violence and conflict (2013): 56-70.

Mayer, Stefanie, Edma Ajanovic, and Birgit Sauer. "Intersections and inconsistencies. Framing gender in right-wing populist discourses in Austria." NORA-Nordic Journal of Feminist and Gender Research 22, no. 4 (2014): 250-266.

Medeiros, Mike. "The language of conflict: The relationship between linguistic vitality and conflict intensity." Ethnicities 17, no. 5 (2017): 627-645. 
Miklian, Jason, and Juan Pablo Medina Bickel. "Theorizing business and local peacebuilding through the "Footprints of Peace" coffee project in rural Colombia." Business \& Society 59, no. 4 (2020): 676-715.

Millar, Gearoid. "Ambition and ambivalence: Reconsidering positive peace as a trans-scalar peace system." Journal of Peace Research (2020): 0022343320941909.

Montiel, Cristina Jayme. "Peace psychologists and social transformation: A Global South perspective." Peace and Conflict: Journal of Peace Psychology 24, no. 1 (2018): 64 .

Montiel, Cristina J., Erwine de la Paz, and Zahra Ibrahim Cerafica. "(De) humanization and trust in an asymmetric Muslim-Christian conflict: Heroes, Kafirs, and Satanas." Peace and Conflict: Journal of Peace Psychology 25, no. 4 (2019): 300 .

Nikolayenko, Olena. "Framing and counter-framing a Peace March in Russia: the use of Twitter during a hybrid war." Social Movement Studies 18, no. 5 (2019): 602-621.

Noble, Mae M., and Christopher J. Fulton. "Pathways to impact for aquatic conservation science via multi-modal communication and stakeholder engagement." Aquatic Conservation: Marine and Freshwater Ecosystems 30, no. 9 (2020): 1791-1797.

Noreen, Erik, and Roxanna Sjöstedt. "Estonian identity formations and threat framing in the post-cold war era." Journal of Peace Research 41, no. 6 (2004): 733-750.

Pepper, Mollie. "Ethnic minority women, diversity, and informal participation in peacebuilding in Myanmar." Journal of Peacebuilding \& Development 13, no. 2 (2018): 61-75.

Peters, Uwe. "Science communication and the problematic impact of descriptive norms." (2021).

Pidgeon, Nick, and Karen Henwood. "Grounded theory." Handbook of Data Analysis, (2004): 625- 648.

Pieczka, Magda, and Oliver Escobar. "Dialogue and science: Innovation in policymaking and the discourse of public engagement in the UK." Science and Public Policy 40, no. 1 (2013): 113-126.

Pruitt, Lesley J. The women in blue helmets: gender, policing, and the UN's first allfemale peacekeeping unit. Univ of California Press, (2016): 84-99.

Rettberg, Angelika. "Need, creed, and greed: Understanding why business leaders focus on issues of peace." Business Horizons 59, no. 5 (2016): 481-492. 
Richmond, Oliver P. "Peace in Analogue/Digital International Relations." Global Change, Peace \& Security 32, no. 3 (2020): 317-336.

Rodríguez, Clemencia. "Community media as performers of peace 1." In Communication and Peace, pp. 289-302. Routledge, 2015.

Rohman, Abdul. "Persistent connection and participation: New media use in postpeace movement Ambon, Indonesia." New Media \& Society 21, no. 8 (2019): 1787-1803.

Saldaña, Johnny. "Coding and analysis strategies." In The Oxford handbook of qualitative research. 2014.

Schneiker, Andrea, Magnus Dau, Jutta Joachim, Marlen Martin, and Henriette Lange. "Hiding in plain sight: Private military and security companies' use of Twitter as a distraction tool." Media, War \& Conflict 12, no. 4 (2019): 483-503.

Scheufele, D. A., \& Tewksbury, D. (2007). Framing, agenda setting, and priming: The evolution of three media effects models. Journal of communication 57, no. 1 (2007): 9-20.

Sehl, Annika, Felix M. Simon, and Ralph Schroeder. "The populist campaigns against European public service media: Hot air or existential threat?." International Communication Gazette (2020): 1748048520939868.

Selin, Cynthia, Kelly Campbell Rawlings, Kathryn de Ridder-Vignone, Jathan Sadowski, Carlo Altamirano Allende, Gretchen Gano, Sarah R. Davies, and David $\mathrm{H}$. Guston. "Experiments in engagement: Designing public engagement with science and technology for capacity building." Public Understanding of Science 26, no. 6 (2017): 634-649.

Shepherd, Laura J. "Constructing civil society: Gender, power and legitimacy in United Nations peacebuilding discourse." European Journal of International Relations 21, no. 4 (2015): 887-910.

Shim, David, and Frank A. Stengel. "Social media, gender and the mediatization of war: exploring the German armed forces' visual representation of the Afghanistan operation on Facebook." Global Discourse 7, no. 2-3 (2017): 330-347.

Shimony, Emma, Aditya Shekhar, Robert O. Bonow, Ali Mokdad, Adam Lupel, Terje Rød-Larsen, Kevin Rudd, and Jagat Narula. "Peace and Epidemiologic Transitions in Patterns of Health and Disease." (2019): 2286-2288.

Sinclair, S., Rockwell, G., \& the Voyant Tools Team. (2012). Voyant Tools (web application). <https://voyant-tools.org/>

Sinclair, S., Ruecker, S., \& Radzikowska, M. (2013). Information visualization for humanities scholars. Literary Studies in the Digital Age, An Evolving Anthology. 
Smallman, Melanie. "Language, power, and public engagement in science." In The Routledge Handbook of Language and Science, pp. 75-84. Routledge, 2019.

Svensson, Isak, and Karen Brounéus. "Dialogue and interethnic trust: A randomized field trial of "sustained dialogue'in Ethiopia." Journal of Peace Research 50, no. 5 (2013): 563-575.

Tesseur, Wine. "Communication Is Aid-But Only if Delivered in the Right Language: An Interview with Translators without Borders on Its Work in Danger Zones." Journal of War \& Culture Studies 12, no. 3 (2019): 285-294.

Thornberg, Robert, and Ciarán Dunne. "Literature review in grounded theory." The Sage handbook of current developments in grounded theory (2019): 206-221.

Translators without Borders. Misunderstanding + misinformation $=$ mistrust: How language barriers reduce access to humanitarian services, reduce the quality of those services and aggravate social exclusion for Rohingya communities. 2019. (https://translatorswithoutborders.org/wp-content/uploads/2019/09/ENG-Crossborder-Report_online_FINAL.pdf).

Tufekci, Zeynep. "'Not this one" social movements, the attention economy, and microcelebrity networked activism." American behavioral scientist 57, no. 7 (2013): 848-870.

Tufekci, Zeynep. "Big questions for social media big data: Representativeness, validity and other methodological pitfalls." In Eighth international AAAl conference on weblogs and social media. 2014.

Tufekci, Zeynep. "Engineering the public: Big data, surveillance and computational politics." First Monday (2014).

Tufekci, Zeynep. "The medium and the movement: Digital tools, social movement politics, and the end of the free rider problem." Policy \& Internet 6, no. 2 (2014): 202-208.

Ustek-Spilda, Funda, and Marja Alastalo. "Software-Sorted Exclusion of Asylum Seekers in Norway and Finland." Global Perspectives 1, no. 1 (2020).

Anna Vachudova, Milada. "Ethnopopulism and democratic backsliding in Central Europe." East European Politics 36, no. 3 (2020): 318-340.

Weder, Natalie, Rebeca García-Nieto, and Daphna Canneti-Nisim. "Peace, reconciliation and tolerance in the Middle East: The impact of people-to-people peace building initiatives among Israeli Jews and Palestinians who lost a firstdegree family member due to the conflict: A pilot study." International Journal of Mental Health 39, no. 4 (2010): 59-81.

Weidmann, Nils B. "Communication networks and the transnational spread of ethnic conflict." Journal of Peace Research 52, no. 3 (2015): 285-296. 
Weidmann, Nils B. "Communication, technology, and political conflict: Introduction to the special issue." Journal of Peace Research 52, no. 3 (2015): 263-268.

Wilkinson, Clare. "Engaging with strangers and brief encounters: Social scientists and emergent public engagement with science and technology." Bulletin of Science, Technology \& Society 34, no. 3-4 (2014): 63-76.

Wong, Pui-Hang. "How can political trust be built after civil wars? Evidence from post-conflict Sierra Leone." Journal of Peace Research 53, no. 6 (2016): 772-785. 